\title{
PENDEKATAN TEORI MANAJEMEN UNTUK PERSIAPAN RUANG MUATAN DI KAPAL
}

MV. VANA

\author{
Cahya, Y. A dan Sitepu Firdaus \\ Jurusan Nautika Politeknik IImu Pelayaran Semarang.
}

E-mail: firdaus.sitepu@yahoo.co.id

\begin{abstract}
Dalam menyediakan tempat untuk mengangkut muatan di atas kapal, maka diperlukan ruang muatan. Ruang muatan tidak selalu mengangkut muatan yang sejenis, tetapi terkadang juga harus berganti muatan lain, apabila terjadi demikian maka ruang muat harus dilakukan pembersihan. Karena sesudah ruang muat sudah dibersihkan tetapi surveyor menyatakan ruang muat kurang bersih maka proses pemuatan tidak boleh dilakukan, sehingga akan terjadi penundaan pemuatan. Dalam penulisan penelitian ini, penulis menjabarkan teori tentang pelaksanaan pembersihan ruang muat di kapal MV. VANA. Metode yang digunakan dalam penelitian ini adalah metode kualitatif yang menghasilkan data deskriptif berupa kata-kata tertulis dari objek yang diteliti. Pengumpulan data dilakukan melalui observasi, melalui metode literatur dan data-datayang berhubungan dengan proses pembersihan ruang muat. Pendekatan teori manajemen digunakan untuk memecahkan masalah yang terjadi pada proses pembersihan ruang muat, teori manajemen ini terdiri dari planning, organizing, actuating, dan controlling. Sehingga akan tercapai suatu tujuan yaitu ruang muat yang bersih dan siap untuk dimuati.
\end{abstract}

Kata kunci: Pembersihan, ruang muat, manajemen 


\section{Cahya, Y. A \& Sitepu Firdaus}

\section{PENDAHULUAN}

Angkutan dengan menggunakan sarana transportasi laut di era globalisasi ini merupakan salah satu yang ekonomis, efisien, dan relatif lebih murah dalam segi penanganan muatan dibanding dengan sarana transportasi lainnya, selain itu dapat dikatakan transportasi yang aman karena jarang terjadi kecelakaan selama pengangkutan muatan dari satu pelabuhan kepelabuhan lain dibandingkan sarana transportasi lain seperti melalui udara atau darat. Transportasi laut juga merupakan sarana penghubung dalam membina hubungan kerja sama antar Negara yang dikatakan maju didalam perekonomiannya.

Dalam perkembangannya kapal laut dibedakan menurut tipe serta jenis muatan yang diangkut. Salah satunya adalah kapal curah atau bulk carrier ship, yaitu kapal yang dirancang, dibuat dan difungsikan sebagai sarana transportasi laut yang umumnya digunakan untuk mengangkut muatan curah dan dimuat secara curah pula.

Adapun muatan curah yang dimuat dikapal curah yang diperdagangkan didunia adalah:

1) Hasil-hasil pertanian, seperti: grain (jagung, gandum, kedelai, beras dan lainnya) yang digunakan untuk perdagangan dunia.

2) Hasil-hasil industri, seperti: fertilizer, ironore, coal, cooper consentrate, nikel dan lainnya yang digunakan untuk keperluan industri.

Pada perusahaan Gurita Lintas Samudera mempunyai beberapa jenis kapal curah, salah satunya adalah kapal curah MV. VANA yang mempunyai 5 palka. Dengan tersedianya ruang muat untuk pemuatan yang baik sudah jelas bahwa muatan akan terawat dengan baik. Sekalipun dalam perjanjian penyewaan (charter party) ruang muat disiapkan oleh penyewa, tetapi masalah tanggung jawab dalam hal pemeriksaan dan persiapan ruang muat, tetap harus dilaksanakan oleh crew kapal. Muatan yang akan dimuat oleh kapal tidak selalu sejenis, apabila kapal mempunyai jadwal pelayaran acak (tramper), maka ada kemungkinan muatan yang akan dimuat berbeda jenis, oleh karena itu pembersihan ruang muatan harus dilaksanakan, sehingga dalam keadaan atau kondisi yang prima dalam penerimaan muatan.

Berdasarkan pengalaman penulis selama praktek diatas kapal MV.VANA, kapal pernah mengalami keterlambatan untuk memuat sehingga operasional kapal pun terganggu, yang disebabkan oleh ruang muat kurang bersih. Hal ini, terjadi dikarenakan kurang telitinya pengecekan ruang muat yang dilakukan setelah pelaksanaan pembersihan. Kemudiansurveyor memeriksa ruang muat ternyata surveyor menyatakan ruang muat kurang bersih dan sertifikat untuk muat pun tidak keluar. Tentunya hal ini tidak dapat dibiarkan begitu saja, yang nantinya akan merugikan perusahaan pelayaran.

Dengan menerapkan fungsi manajemen yaitu planning, organizing, actuating dan controlling diatas kapal dalam mempersiapkan ruang muat tersebut, akan tercapai tujuan yang diinginkan, yaitu ruang muat yang siap untuk dimuat sehingga tidak terjadi penundaan muatan dan dapat menunjang kelancaran operasional kapal. Sehubungan dengan hal tersebut diatas, penulis penelitian ini memilih judul: "Persiapan Ruang Muatan di Kapal MV. VANA Melalui Pendekatan Teori Manajemen". 
Dalam suatu penulisan ilmiah perumusan masalah atau problematika masalah merupakan hal yang sangat penting, karena perumusan masalah akan memudahkan dalam melakukan penelitian dan dalam mencari jawaban yang lebih akurat.

Berdasarkan latar belakang penelitian yang telah dikemukakan, maka penulis dapat merumuskan masalah sebagai berikut:

1) Bagaimana gambaran persiapan ruang muat untuk kapal MV. VANA?

2) Bagaimana pendekatan manajemen dapat diterapkan dalam persiapan ruang muat di kapal MV. VANA ?

\section{KAJIAN PUSTAKA}

Persiapan Ruang Muat

Menurut Spencer (2011: 1) Persiapan ruang muat bukan hanya masalah menyapu, membersihkan atau mencuci bawah palka. Ada juga sejumlah hal yang perlu dipertimbangkan, dan apabila gagal untuk mematuhi prosedur yang baik akan dapat mengakibatkan klaim substansial. Kurangnya pengetahuanjuga dapat menjadi penyebab yang mendasari klaim utama.

Pengertian Teori

Menurut Labovitz dan Hagedorn (2014: 1) teori adalah serangkaian bagian atau variabel, definisi, dan dalil yang saling berhubungan yang menghadirkan sebuah pandangan sistematis mengenai fenomena denganmenentukan hubungan antar variabel, dengan menentukan hubungan antar variabel, dengan maksud menjelaskan fenomena alamiah.

Pengertian Manajemen

Menurut Manullang (2001:14) manajemen mengandung tiga pengertian: pertamamanajemen sebagai suatu proses, kedua manajemen sebagai sekumpulan orangorang yang melakukan kegiatan manajemen dan ketiga manajemen sebagai suatu seni (art)dan sebagai suatu ilmu.

Di dalam proses manajemen dipimpin oleh seorang manajer. Manajer adalahseseorang yang pekerjaannya bertugas untuk merencanakan, mengorganisir, memberi motivasi, dan mengawasi pekerjaan dari orang lain. Di atas kapal, peran seorang manajer dilaksanakan oleh Nahkoda kapal.

Manajemen Persiapan Ruang Muat 
Menurut Manullang (2001: 14) manajemen mengandung tiga pengertian: pertama manajemen sebagai suatu proses, kedua manajemen sebagai sekumpulan orang-orang yang melakukan kegiatan manajemen dan ketiga manajemen sebagai suatu seni (art)dan sebagai suatu ilmu..

Dari definisi tersebut, Manullang mengemukakan bahwa manajemen mengandung beberapa unsur, yakni unsur fungsi, unsur sasaran dan unsur tujuan. Maka dari pengertian manajemen dan penanganan dapat disimpulkan bahwa manajemen persiapan ruang muatan di atas kapal curah yaitu suatu usaha perencanaan, pengorganisasian, pengarahan, dan pemberian motivasi kepada awak kapal dan pengawasan terhadap awak kapal tersebut beserta mekanisme kerja yang akan dilaksanakan dalam menangani persiapan ruang muatan di atas kapal curah. Adapun tujuan yang akan dicapai adalah ruang muat siap untuk dimuat dan proses pekerjaan dari awal hingga akhir dapat berjalan dengan lancar sehingga tidak terjadi penundaan pemuatan dan menunjang kelancaran operasional kapal.

\section{Kerangka berfikir}

Agar penulisan penelitian ini menjadi jelas dan bermanfaat,maka penulis memberikan kerangka berfikir yang diambil untuk memudahkan pemahaman dari judul yang penulis ajukan.Kerangka pemikiran ini menjelaskan bagaimana persiapan ruang muatan di kapal MV. VANA Ialu apa kendala-kendala yang menyebabkan terjadinya penundaan pemuatan, serta dengan mengaplikasikan teori manajemen agar pelaksanaan pembersihan ruang muat berjalan lancar sesuai perencanaan sehingga ruang muat bersih dan dapat dimuati muatan lain.

\section{METODE PENELITIAN}

\section{Metode Kualitatif}

Peneliti menggunakan metode kualitatif, Raco (2010: 07), bahwa penelitian kualitatif merupakan suatu pendekatan atau penelusuran untuk mengeksplorasi dan memahami suatu gejala sentral.Untuk mengerti gejala sentral tersebut peneliti mewancarai peserta penelitian atau partisipan dengan mengajukan pertanyaan yang umum dan agak luas.

\section{Metode Deskriptif}

Menurut Nazir (2005: 54). MetodeDeskriptif merupakan suatu metode dalam meneliti status sekelompok manusia, suatu objek, suatu sistem pemikiran ataupun suatu kelas peristiwa pada masa sekarang. Tujuan dari penelitian deskriptif ini adalah untuk membuat deskriptif, gambaran atau lukisan secara sistematis, faktual dan akurat mengenai fakta-fakta, sifat-sifat serta hubungan antar fenomena yang diselidiki

\section{Lokasi dan Waktu Penelitian}


Pada pelaksanaan proses penelitian penelitian ini penulis melakukannya pada saat praktek laut (prala) di perusahaan Gurita Lintas Samudera, yang memiliki kantor di Indonesia dengan alamat Jalan Tomang Raya 47 E, Jakarta-11440. Sedangkan dalam melaksanakan penelitian, peneliti melakukan di:

1) Peneliti melakukan penelitian di kapal MV. VANA, yang merupakan kapal jenis curah milik perusahaan PT. Gurita Lintas Samudera yang berkantor di jalan Tomang Raya 47 E, Jakarta-11440. Kapal tersebut beroperasi dibeberapa pelabuhan di Indonesia dengan membawa muatan curah dengan line acak.

2) Waktu penelitan adalah pada saat penulis melakukan praktek laut selama dua belas bulan di kapal MV. VANA yang dioperasikan oleh perusahaan Gurita Lintas Samudera dari tanggal 21 Desember 2012 sampai 26 Desember 2013 sebagai deck cadet. Peneliti melakukan penelitian langsung terhadap kegiatan Pembersihan ruang muat di atas kapal MV. VANA.

\section{Metode Analisis Data}

Dalam penulisan penelitian ini, penulis menggunakan metode analisa data yaitu sesuai dengan teori manajemen,

Analisis data adalah proses mencari dan menyusun secara sistematis data yang diperoleh dari hasil pengamatan, catatan lapangan, dan dokumentasi dengan cara mengorganisasikan data ke sintesis, menyusun ke dalam pola, memilih mana yang penting dan yang akan dipelajari, dan membuat kesimpulan sehingga mudah dipahami oleh diri sendiri maupun orang lain. Dalam teori manajemen menjelaskan bahwa tahap analisa dibagi menjadi 4 tahapan, yaitu planning, organizing, actuating dan controlling. Planning adalah penentuan tujuan dan sasaran yang ingin dicapai dan bagaimana cara mencapainya. Dalam hal ini adalah perencanaan yang matang terhadap proses persiapan ruang muatan agar terlaksana efektif dan efisien. Organizing adalah pengalokasian sumber daya seoptimal mungkin dan memberi jasa informasi juga pelayanan.Dalam hal ini adalah mempekerjakan tenaga kerja yang berkualitas dan juga penggunaan alat pembersihan yang sesuai standard kerja.Actuating tindakan seorang pemimpin organisasi untuk memberi pelatihan, pembinaan, dan motivasi sehingga pekerja dapat bekerja sebaik mungkin, bagaimana cara mualim 1 memberi motivasi kepada anak buahnya agar disiplin kerja semakin baik sehingga pembersihan dapat berjalan dengan cepat. Controlling adalah suatu pengawasan yang dilakukan seorang pemimpin, dalam arti memonitor apakah kinerja pelaksanaan kegiatan menyimpang, baik atau tidak baik bila dibandingkan dengan yang direncanakan.Dalam hal ini adalah seorang mualim 1 harus melakukan pengawasan terhadap crew yang melakukan pembersihan palka untuk mempersiapkan ruang muat dengan baik dan sesuai standard kerja yang aman, efektif dan efisien.

\section{DISKUSI}

Penulis melakukan penelitian penelitian ini diatas kapal MV. VANA dimana penulis melaksanakan praktek laut selama kurang lebih 12 bulan dari tanggal 21 desember 2012 
sampai dengan tanggal 26 desember 2013. Kapal MV. VANA adalah salah satu kapal curah yang dimiliki oleh perusahaan armada kapal GURITA LINTAS SAMUDERA dan berkebangsaan Indonesia.

\section{Gambaran Objek Penelitian}

Kapal MV. VANA merupakan kapal jenis bulk carrier yang mempunyai 5 buah palka, lima buah palka tersebut digunakan untuk memuat dan membawa muatan curah, beberapa muatan curah yang pernah dimuat di palka MV. VANA yaitu: pupuk, batu bara, nikel dan cooper consentrate. Muatan pupuk yang biasanya dimuat di palka MV. VANA kurang lebih $38.600 \mathrm{mt}$, lalu muatan batu bara bisa dimuat kurang lebih $37.300 \mathrm{mt}$ dan muatan cooperconsentrate bisa dimuat kurang lebih $26.500 \mathrm{mt}$.

Kapasitas dari palka MV VANA ada 2 jenis Ukuran volume, ukuran volume yang pertama adalah graincapacity dan yang kedua adalah balecapacity, pada graincapacity palka nomor 1 mempunyai volume 9.991,50 cbm, palka nomor 2 mempunyai volume 11.170,80 cbm, palka nomor 3 mempunyai volume $11.197,50 \mathrm{cbm}$, palka nomor 4 mempunyai volume $11.263,80 \mathrm{cbm}$ dan palka no 5 mempunyai volume 10.515,10 cbm, jadi total graincapacity palka di MV. VANA adalah 54.138,70 cbm. Sedangkan untuk Ukuran balecapacity di palka nomor 1 mempunyai volume 9.796,50 cbm, palka nomor 2 mempunyai volume 10.989,80 cbm, palka nomor 3 mempunyai volume $11.011,60 \mathrm{cbm}$, palka nomor 4 mempunyai volume $11.080,20 \mathrm{cbm}$ dan palka nomor 5 mempunyai volume 10.356,60 cbm, jadi total balecapacity palka di kapal MV. VANA adalah $53.231,70 \mathrm{cbm}$.

Sesuai dengan judul penelitian yaitu "Persiapan ruang muatan di kapal MV. VANA melalui pendekatan teori manajemen" maka sebagai depenelitian data, penulis akan memamparkan tentang pelaksanaan persiapan ruang muatan dan juga pelaksanaan pembersihanpalka agar tidak terjadi penundaan pemuatan. Paparan yang penulis berikan adalah hasil pengamatan selama melaksanakan praktek laut selama 12 bulan di MV. VANA, diharapkan agar pembaca lebih mudah memahami tentang semua hal yang terjadi di atas kapal, khususnya dalam proses mempersiapkan ruang muatan yaitu pembersihan palka.

Hasil Penelitian

Berdasarkan penelitian penulis tentang persiapan ruang muatan di kapal MV.VANA.Pengaplikasian teori manajemen yang terdiri dari planning, organizing, actuating dan controlling digunakan untuk menyelesaikan permasalahan yang terjadi di kapal MV.VANA.Penulis menemukan masalah-masalah yang menyebabkan tertundanya pemuatan dan faktor apa saja yang menyebabkan tertundanya pemuatan adalah:

1) Pada tanggal 6 mei sampai tanggal 8 mei 2013 saat kapal dalam pelayaran dari Bontang menuju Gresik, pembersihan ruang muat dilakukan dengan:

a) Tahap pertama cleaning, Membersihkan ruang muatan dengan penyapuan (sweeping), disekop (shoveling) dan scraping sisa-sisa pemuatan yang ada diruang muat dikumpulkan lalu dimasukkan kedalam satu wadah/drum yang diikat dengan seutas tali 
lalu ditarik keatas dek dengan menggunakan crane kapal yang selanjutnya akan dibuang kelaut.

b) Tahap washing dan drying, Pembersihan tahap kedua adalah dengan penyemprotan melalui media air laut dengan tujuan memudahkan proses pembersihan pada ruang muat dari sisa-sisa kotoran. Pompa got harus berfungsi dengan baik agar dapat menghisap air laut sekaligus sisa pupuk yang ada dalam palka, sehingga dapat menghindari genangan air didalam ruang muat. Tahap selanjutnya adalah mengeringkan ruang muat (drying). Drying yaitu pengeringan ruang muat dari genangan air bekas penyemprotan dengan menggunakan pompa hisap pada got palka, setelah pompa tidak memungkinkan lagi untuk menghisap, maka air yang masih tertinggal pada bagian yang berlekuk dikeringkan dengan cara dimopping (pel) bersamaan dengan membersihkan endapan sisa-sisa muatan. Setelah itu tutup ruang muat (hatchcover) dan peranginan (ventilasi) dibiarkan terbuka untuk mendapatkan peranginan dan pengeringan oleh matahari agar mempercepat pengeringan dengan ketentuan keadaan cuaca mengizinkan artinya tidak atau sedang hujan. Selain itu, untuk mempercepat proses pengeringan terutama pada permukaan lantai ruang muat yang agak cekung kedalam digunakan busa dengan cara menggosokkan ke bagian yang cekung sehingga busa dapat menyerap air di bagian tank top yang cekung tersebut dan selain itu got palka juga dikeringkan dan dibersihkan dari sisa-sisa muatan yang terhisap.

c) Tahap rechecking, Tahap terakhir adalah pengecekan ruang muat seperlunya.Setelah ruang muat kering dan benar-benar bersih, maka biasanya dilakukan penyekrapan dari karat-karat yang ada dalam ruang muat.Kotoran-kotoran karat yang sudah discrap tadi disapu dan dikumpulkan kedalam wadah dan selanjutnya diangkut keatas deck.

Persiapan maupun pembersihan ruang muat telah selesai, maka setelah kapal tiba di pelabuhan Gresik, Jawa Timur kapal langsung sandar, nahkoda langsung menemui surveyor dan mualim I. Setelah survey ternyata kapal tidak memenuhi persyaratan kebersihan karena di bagian hatch coaming palka masih terdapat sisa-sisa pupuk. sehingga terjadi penundaan pemuatan karena masih ada sisa sisa pupuk pada bagian hatch coaming setelah pembersihan.

Surveyor lalu memberikan kesempatan kapada pihak kapal untuk mempersiapkan kembali sampai palka benar-benar siap dan hatch coaming bersih dari sisa-sisa pupuk. Akhirnya, hatchcoaming dibersihkan sampai bersih.Setelah selesai maka surveyor dipanggil kembali untuk memeriksa ruang muat.Surveyor mengadakan pemeriksaan ulang dan setelah dinilai bersih maka surveyor memberikan surat keterangan untuk muat.

Sesuai hasil observasi pada saat melakukan proses persiapan ruang muat dan pada saat melakukan pembersihan palka adalah penundaan pemuatan yang terjadi dikarenakan persiapan palka yang kurang baik dan teliti yang dilakukan oleh crew kapal saat pembersihan palka. Terbukti dengan adanya sisa-sisa pupuk di bagian hatchcoaming.

2) Fakta yang lain menyebutkan ketika kapal dari Cigading, Jawa Barat, menuju Bontang, Kalimantan Timur pada tanggal 7 juli sampai tanggal 10 juli 2013 untuk memuat pupuk. 


\section{Cahya, Y. A \& Sitepu Firdaus}

Waktu perjalanan yang dibutuhkan pada pelayaran tersebut relatif singkat, yaitu 3 hari. Satu hari digunakan oleh crew deck untuk membersihkan kotoran yang ada diatas main deck, lalu waktu yang 2 hari digunakan untuk melakukan pembersihan palka. Crew yang bekerja saat itu berjumlah 8 orang yang terdiri dari:

a) 3 orang juru $A B$ (jurumudi)

b) 3 orang Taruna praktek laut

c) 1 orang bosun

d) 1 orang mistri

Keesokan harinya mualim 1 berencana untuk membersihkan di dalam palka.Crew yang bekerja di dalam palka hanya 5 orang, sedangkan dua orang lainnya standby diatas palka jika ada sesuatu yang di butuhkan oleh crew yang ada didalam palka. Selama dua hari pembersihan palka dilaksanakan oleh crew dengan tergesa-gesa untuk mencapai target yang ditentukan. Setibanya dipelabuhan surveyor bersama mualim I mengecek seluruh ruang muat yang berjumlah 5 palka.Dan ternyata surveyor menyatakan bahwa palka 4 dan 5 belum bisa dimuat karena masih banyak genangan air di atas tank top yang cekung.Dengan demikian surveyor memberi kesempatan pada pihak kapal untuk mengeringkan genangan air yang ada dalam ruang muat tersebut.Semua $A B K$ dek turun ke dalam ruang muat untuk mengeringkannya.

Sesuai hasil observasi yang telah dilakukan penulis hal-hal yang menyebabkan tertundanya pemuatan adalah:

a) pelaksanaan pembersihan ruang muat yang dilaksanakan oleh crew kapal terkesan tergesa-gesa sehingga dalam pelaksanaannya tidak maksimal, ini disebabkan karena waktu yang di berikan sangat terbatas. Lamanya perjalanan sangat mempengaruhi dalam pelaksanaan pembersihan palka tersebut. Crewdeck yang berjumlah 8 orang terdiri dari 3 orang jurumudi, 3 orang cadet, 1 orang bosun dan 1 orang mistri tidak cukup untuk membersihkan palka yang berjumlah lima buah sehingga crew harus bekerja esktra agar dapat menyelesaikan pekerjaan tersebut sesuai waktu yang ditentukan sehingga ruang muat siap dimuat dipelabuhan. Kemudian saat melakukan pembersihan ruang muat masih terdapat sisa-sisa genangan air di tank top palka karena proses pengeringan palka kurang maksimal. Yang seharusnya hatch cover palka perlu dibuka agar tank top dapat terkena sinar matahari sehingga cepat kering, tetapi karena tergesa-gesa maka ABK hanya fokus untuk pembersihan semua palka terlebih dahulu.

b) Waktu yang relatif singkat dalam pelaksanaan pembersihan palka. Luas palka di kapal MV. VANA yaitu 288 meter dengan panjang 19,2 meter, lebar 15 meter dan tinggi 18 meter. Jumlah crew yang melaksanakan pembersihan yaitu 8 orang, sedangkan dalam 1 periode kerja jam 08.00-12.00 para crew melakukan proses scraping, shoveling dan mengumpulkan sisa muatan nikel ke drum terlebih dahulu, lalu periode jam 13.00-17.30 para crew melakukan penyemprotan dengan air sehingga periode kerja normal yaitu jam 08.00-17.30 crew baru bisa menyelesaikan satu palka. Dalam keadaan ini dapat dihitung bahwa 5 palka seharusnya diperlukan waktu 5 hari dalam periode kerja normal, 
akan tetapi waktu pelayaran hanya 3 hari saja sehingga masih banyak sisa genangan air sisa penyemprotan yang belum kering.

\section{Pembahasan Masalah}

Ruang muat (palka) adalah suatu ruangan di atas kapal curah yang digunakan khusus untuk memuat muatan curah.Sebelum memuat muatan, ruang muat harus dipersiapkan dengan baik.Persiapan ruang muat yaitu dengan melakukan pembersihan palka.Pembersihan palka dilakukan berdasarkan jadwal dalam memuat muatan, karena route pelayaran di kapal MV. VANA acak (tramper) maka muatan yang akan dimuat kadang sejenis tetapi kadang muatan yang akan dimuat juga tidak sejenis (ganti muatan). Oleh karena itu proses pembersihan yang dilakukan juga akan berbeda.

Teori manajemen digunakan sebagai solusi untuk menyelesaikan masalah tertundanya pemuatan yang terjadi di atas kapal MV.VANA. Pada pembahasan masalah, penulis menyajikan data yang digunakan sebagai pemecahan masalah dengan metode aplikasi manajemen, yaitu planning, organizing, actuating dan controlling dengan membandingkan apabila akan melaksanakan pembersihan dengan muatan yang sama lalu melaksanakan pembersihan dengan muatan yang berbeda. Data yang ada akan dibandingkan agar dari permasalahan tersebut ditemukan hasil analisa yang efektif dan efisien untuk memecahkan masalah. Data yang penulis sajikan yaitu data yang terjadi sewaktu penulis melakukan pengamatan secara langsung dan saat itu pula terjadi permasalahan.

Berikut merupakan penjelasan tentang teori manajemen yang digunakan untuk dasar melaksanakan pembersihan ruang muatan di kapal MV. VANA:

1) Planning (perencanaan), Dari data yang diperoleh perencanaan merupakan salah satu alternative langkah awal dalam menyelesaikan masalah dengan menyesuaikan waktu pelayaran yang membatasi persiapan ruang muatan curah dengan rincian sebagai berikut:

a) Merencanakan kapan pelaksanaan pembersihan ini dimulai.

b) Merencanakan pembersihan dimulai dari palka yang got hisapnya lancar.

c) Merencanakan tahap-tahap dalam persiapan pembersihan ruang muatan curah meliputi: cleaning, washing, driying dan rechecking.

d) Merencanakan jumlah crew yang akan melakukan pembersihan.

e) Merencanakan pembagian tugas-tugas pembersihan.

2) Organizing (pengorganisasian), Organizing merupakan suatu proses mekanisme untuk mengatur jumlah para crew, alat apa saja yang digunakan dan bagaimana agar planning yang dibuat bisa tercapai seusai target. Dengan cara mengelompokkan serta membagi tugas-tugas atau pekerjaan para crew dengan pengawasan Mualim 
1. Pelaksaaan pembersihan palka menggunakan cara pengoganisasian yang mana dalam pelaksanaanya kerja harus dapat dicapai dengan rencana kerja yang telah disusun. Kecuali memang ada hal-hal khusus sehingga perlu dilakukan penyesuaian dengan hal khusus tersebut. Pengorganisasian mempunyai 3 unsur:

a) Manusia, Pengertian dari manusia tersebut yaitu crew kapal. Crew kapal tersebut tidak lain merupakan berapa jumlah ABK yang akan melaksanakan pembersihan palka, yaitu terdiri dari bosun, mistri, 3 orang cadet, 3orangjurumudi dan menentukan apakah perwira dek ikut serta atau tidak dalam proses pembersihan.

b) Alat, Pengertian dari alat adalah benda-benda atau peralatan apa saja yang digunakan untuk melaksanakan pembersihan palka apabila muatan yang sejenis maupun tidak sejenis.

c) Waktu, Pengertian waktu merupakan kapan pelaksanaan pembersihan akan dimulai serta kapan pembersihan selesai.

3) Actuating (pelaksanaan), Actuating merupakan suatu tindakan untuk menggerakkan semua anggota crew untuk bekerja dan berusaha untuk mencapai sasaran atau target pembersihan palka sesuai dengan perencanaan yang telah dibuat dan diorganisir. Dalam hal ini yang dibutuhkan adalah kepemimpinan yaitu seorang Mualim 1. Actuating adalah pelaksanaan untuk bekerja. Hal penting untuk diperhatikan dalam pelaksanan (actuating) pembersihaan palka para crew untuk pembersihaan palka jika:

a) Merasa yakin akan mampu mengerjakan tugas atau pekerjaan sesuai target yang telah ditentukan menyesuaikan waktu pelayaran pada saat itu agar tugas tersebut dapat diselesaikan sesuai rencana.

b) Para crew harus yakin bahwa pekerjaan tersebut memberikan manfaat bagi dirinya.

c) Tugas tersebut merupakan kepercayaan bagi seorang Mualim yang memimpin pelaksanaan pembersihaan palka termasuk memberi pengarahaan dan pengawasaan serta motivasi kepada para crew agar melaksanakan pembersihan palka dengan sungguh-sungguh.

d) Para crew yang ikut dalam pelaksaan pembersihaan palka tidak merasa terbebani tugas lain yang lebih penting. Sehingga proses pelaksanaan pembersihaan palka dapat selesai sesuai target perencanaan yang telah disusun.

4) Controlling (pengawasan), Controlling merupakan tindakan pengawasan dan pengendalian yang dilakukan oleh Mualim 1 untuk mengamati secara terus-menerus pelaksanaan kegiataan atau tugas sesuai dengan rencana yang telah disusun, diorganisasi dan dilakukan oleh para crew serta anak buahnya saat pembersihaan palka serta mengadakan koreksi jika diperlukan. Fungsi controlling atau pengawasaan adalah fungsi Mualim 1 memiliki tugas, wewenang dan menjalankan pelaksanaan pembersihaan palka perlu dilakukan pengawasaan agar berjalan sesuai dengan 
tujuan, yang telah disusun. Dengan demikian pengawasaan merupakan suatu kegiatan untuk mengendalikan pelaksanaan dapat berjalan sesuai dengan rencana dan memastikan apakah tujuan organisasi tercapai. Bentuk pengawasaan yang dilakukan Mualim 1 salah antara lain:

a) Memastikan aktivitas sesuai dengan perencanaan yang telah disusun.

b) Mualim 1 harus menggerakkan para crew kapal ke arah yang telah ditentukan saat melakukan pembersihan palka.

c) Checklist hasil pelaksanaan pembersihan.

Apabila terjadi penyimpangan saat proses pembersihaan palka, dimana letak kesalahan itu dan bagaimana pula tindakan apa yang diperlukaan untuk mengatasinya dengan cara ditegur dan memberi peringatan, Mualim 1 harus memiliki tahap-tahap dalam pengawasaan seperti:

a) Penetapan standar pelaksanaan pembersihaan palka dari awal sampai selesai.

b) Membandingan kegiataan dengan standard dan menganalisa apabila terjadi penyimpangan seperti anak buah yang bermalas-malasan dalam bekerja atau tidak mengikuti prosedur yang telah ditetapkan.

Berikut ini merupakan penjelasan tentang pengaplikasian teori manajemen agar pembersihan dapat berjalan dengan efektif dan efisien, baik pembersihan muatan sejenis maupun muatan yang tidak sejenis.

1) Karena route pelayaran yang tramper (acak), maka tujuan pelayaran kadang tetap dan kadang berubah. Apabila tujuan pelayaran selanjutnya masih sama dengan sebelumnya seperti MV. VANA yang sebelumnya memuat nikel di Marombo, Sulawesi Tenggara. Lalu kemudian muatan dibongkar di Cigading, Jawa Barat. Dan selanjutnya kapal akan kembali lagi ke Marombo untuk memuat nikel lagi, maka pembersihan yang akan dilakukan tidak terlalu berat karena muatan tidak berubah sehingga tidak memerlukan pembersihan dengan media air.

Tabel 1 - Aplikasi Teori Manajemen Muatan Sejenis

\begin{tabular}{|c|lr|}
\hline $\begin{array}{c}\text { APLIKASI } \\
\text { TEORI } \\
\text { MANAJEME } \\
\mathbf{N}\end{array}$ & \multicolumn{2}{|l|}{ PEMBERSIHAN MUATAN SEJENIS } \\
\hline Planning & $\begin{array}{l}\text { a. Merencanakan } \\
\text { pekerjaan }\end{array}$ & pembersihan \\
& akan dimulai. & \\
& $\begin{array}{l}\text { b. Merencanakan jumlah crew } \\
\text { yang akan ikut untuk } \\
\text { melakukan pembersihan. }\end{array}$ \\
& c. Merencanakan pembagian \\
& tugas-tugas & dalam \\
\hline
\end{tabular}




\begin{tabular}{|c|c|}
\hline & $\begin{array}{l}\text { pelaksanaan pembersihan. } \\
\text { d. Mengadakan safety } \\
\text { briefing. }\end{array}$ \\
\hline Organizing & $\begin{array}{l}\text { a. Manusia } \\
\text { Mengkoordinasikan jumlah } \\
\text { crew yang akan } \\
\text { melaksanakan } \\
\text { pembersihan, } \\
\text { pembagian tugas sesuai } \\
\text { rencana. } \\
\text { b. Alat } \\
\text { Mengorganisasikan } \\
\text { peralatan apa saja yang } \\
\text { digunakan untuk melakukan } \\
\text { pembersihan. } \\
\text { c. Waktu } \\
\text { Mengorganisasikan waktu } \\
\text { pembersihan dimulai dan } \\
\text { waktu pembersihan selesai, } \\
\text { termasuk menentukan jam } \\
\text { istirahat. }\end{array}$ \\
\hline Actuating & $\begin{array}{l}\text { Melakukan pembersihan sesuai } \\
\text { pembagian tugas yaitu } \\
\text { sebagian ABK berada di atas } \\
\text { palka lalu sebagian lagi } \\
\text { berada di dalam palka. }\end{array}$ \\
\hline Controlling & $\begin{array}{l}\text { Pengawasan mualim l pada } \\
\text { saat melakukan } \\
\text { pembersihanpalka dengan } \\
\text { memastikan bahwa } \\
\text { pelaksanaan pembersihan } \\
\text { sesuai perencanaan. }\end{array}$ \\
\hline
\end{tabular}

Penjelasan untuk pembersihan palka muatan sejenis yaitu:

a) Planning adalah suatu proses perencanaan dengan menetapkan suatu tindakan awal untuk melaksanakan pembersihan palka. Adapun perencanaan untuk pembersihan palka muatan sejenis tersebut adalah:

1) Merencanakan kapan pelaksanakan pembersihan akan dimulai dan kapan pembersihanharus selesai. Apabila jarak yang ditempuh dekat maka pelaksanaan pembersihan akan dilaksanakan dengan cepat, tetapi tidak lepas dari tujuan yang akan dicapai yaitu palka yang siap untuk dimuati. Sebaliknya jika jarak tempuh jauh maka akan ada banyak waktu yang akan bisa digunakan untuk melaksanakan pembersihan sehingga palka siap untuk dimuati kembali.

2) Merencanakan proses pelaksanaan pembersihan dimulai dari palka mana terlebih dahulu, agar para ABK kapal tidak bingung dalam mempersiapkan alat yang akan digunakan dan dibawa masuk ke dalam palka yang akan dibersihkan. 
3) Merencanakan berapa jumlah ABK yang akan ikut dalam pelaksanaan pembersihan palka. Untuk pembersihan palka apabila muatan selanjutnya sejenis berarti tidak akan menggunakan media air sehingga cukup ABK deck saja yang terlibat.

4) Merencanakan pembagian tugas dari masing-masing ABK kapal agar nantinya dapat berjalan sesuai tugasnya serta akan lebih memudahkan untuk pelaksanaan pembersihan nantinya.

5) Mengadakan safety briefing agar pelaksanaan pembersihan berjalan aman.

Safetybriefing merupakan suatu pertemuan seluruh crew sebelum melakukan suatu pekerjaan, safetybriefing berisi arahan-arahan dari captain maupun mualim agar pelaksanaan pembersihan palka berjalan aman dan tidak terjadi kecelakaan atau kesalahan yang dapat mengakibatkan crew cidera. Beberapa point yang diperhatikan dalam safetybriefing adalah:

a) Memperhatikan keselamatan kerja para crew dengan memperhatikan alat keselamatan kerja (safetyequipment).

b) Memperhatikan permintaan para crew untuk fasilitas atau sarana prasarana yang dibutuhkan dalam kegiatan pembersihan palka.

c) Memperhatikan keselamatan kapal dari kerusakan karena benturan dan lain sebagainya akibat dari kelalaian para crew.

d) Organizing merupakan mekanisme untuk membuat perencanaan menjadi kenyataan, serta untuk membuat mengatur dan mengelompokkan serta membagi tugas-tugas atau pekerjaan agar pembersihan palka dapat dicapai dengan efisien. pengorganisasian mempunyai 3 unsur yang harus diperhatikan yaitu:

1) Manusia, Pengertian dari manusia tersebut yaitu crew kapal.Crew kapal tersebut tidak lain merupakan berapa jumlah $A B K$ yang akan melaksanakan pembersihan palka. Apabila muatan yang akan dimuat selanjutnya sejenis maka jumlah ABK yang akan melaksanakan pembersihan tidak perlu banyak. Cukup dengan ABK deck saja tanpa bantuan $A B K$ mesin proses pembersihan dapat berjalan. Jarak tempuh juga berpengaruh dalam jumlah ABK yang akan ikut dalam pelaksanaan pembersihan, sesuai perencanaan dengan perencanaan sebelumnya yaitu cukup ABK deck saja yang melaksanakan pembersihan. Dalam proses pengorganisasian ini juga akan dilakukan pembagian tugas-tugas agar tujuan yaitu ruang muat yang siap untuk dimuat dapat tercapai. Pembagian tugas tersebut seperti berapa orang yang akan turun ke palka untuk membersihkan palka dan berapa orang akan standby di atas palka untuk membuang sisa muatan dari dalam palka yang suda dibersihkan oleh ABK yang bekerja di dalam palka. Selain itu mualim 1 bertugas untuk mengkoordinir serta mengatur anak buahnya agar dapat melaksanakan proses pembersihandengan baik.

2) Alat, Pengertian dari alat adalah alat-alat apa saja yang digunakan untuk melaksanakan pembersihan palka apabila muatan yang akan dimuat selanjutnya sejenis. Peralatan yang digunakan untuk melakukan pembersihan palka tersebut yaitu sapu, sekop, drum yang sudah dipasang seling, scrap, engkrak serta mempersiapkan 


\section{Cahya, Y. A \& Sitepu Firdaus}

crane kapal untuk membuang sisa-sisa muatan yang telah dikumpulkan ke dalam drum.

3) Waktu, Pengertian waktu merupakan kapan pelaksanaan pembersihan akan dimulai serta kapan pembersihan selesai. Selain itu dalam waktu satu hari pembersihan ditentukan mulai pada pukul berapa sampai dengan pukul berapa, apakah akan diadakan coffe time atau tidak. Jika jarak yang akan ditempuh kapal dekat maka sebaiknya coffe time ditiadakan agar waktu pelaksanaan pembersihan palka lebih banyak sehingga proses pembersihan juga bisa cepat selesai. Namun apabila jarak yang akan ditempuh kapal jauh, maka akan banyak waktu untuk melaksanakan pembersihansehingga waktu istirahat seperti coffe time boleh diadakan.

b) Actuating, merupakan pelaksanaan yang dilakukan setelah perencanaan dan pengorganisasian yaitu untuk menggerakkan semua anggota crew bekerja dengan sendirinya atau dengan kesadaran bersama-sama untuk mencapai tujuan. Pelaksanaan yang dilakukan untuk melakukan pembersihan palka apabila muatan yang akan dimuat selanjutnya sejenis maka ABK yang bertugas membersihkan dalam palka melakukan penyapuan terhadap sisa-sisa muatan yang ada di tanktop maupun di dinding palka. Sisa-sisa yang menempel di dinding palka dapat di scrap agar jatuh ke bawah. Setelah jatuh ke bawah semua maka sisa-sisa muatan tersebut dapat disapu dan dikumpulkan disatu tempat, lalu setelah terkumpul di satu tempat drum yang sudah dipasang seling didekatkan ke tumpukan sisa-sisa muatan tersebut kemudian tumpukan sisa-sisa muatan tersebut disekop dan dimasukkan ke dalam drum. Setelah semua sisa-sisa muatan sudah masuk ke dalam drum, maka drum tersebut siap ditarik dengan crane kapal untuk dibuang ke laut. Caranya dengan ujung crane yang sudah dipasang ganco, lalu ganco diarahkan ke arah seling yang sudah dipasangkan ke drum dan ganco dikaitkan ke seling lalu heaveup pelan crane dan kemudian setelah drum sudah sampai maindeck maka ABK yang standby di atas akan melepas kaitan ganco tersebut dan menumpahkan isi drum ke maindeck. Lalu sisa-sisa muatan tersebut dapat disekop dan dibuang ke laut.

c) Controlling, merupakan proses untuk mengamati yang dilakukan oleh pemimpin terhadap anak buahnya secara terus-menerus sehingga pekerjaan dapat selesai sesuai dengan rencana. Pada saat melaksanakan pembersihan palka yang bertugas sebagai pemimpin kerja yaitu chief officer (mualim 1). Maka mualim 1 harus melakukan pengawasan terhadap ABK yang melaksanakan pembersihan palka. Pengawasan tersebut dilakukan secara penuh dengan selalu memeriksa kinerja ABK apakah mereka melakukan pembersihan dengan baik. Apabila ada yang tidak serius melakukan tugasnya maka mualim 1 harus menegur dan memberikan perintah agar ABK tersebut tidak bermalas-malasan dan tetap melakukan pekerjaan pembersihan palka sesuai yang telah direncanakan tadi. Tujuan melakukan pembersihanpalka adalah palka siap untuk dimuati. Apabila palka tidak bersih maka palka tersebut belum siap untuk dimuati sehingga tujuan belum tercapai. Dalam hal ini tugas seorang mualim 1 harus menggerakkan para crew kapal ke arah yang telah ditentukan saat melakukan pembersihan palka sehingga tidak hanya melakukan pengawasan saja, tetapi juga seorang atasan ikut andil dan terjun langsung saat pembersihan palka serta memberi pengarahan apa saja yang dibutuhkan oleh para crew, sehingga tercipta kinerja yang baik antara atasan dan bawahan dan tak ada anggapan kalau 
atasan itu hanya bisa memerintah tetapi bisa memberi contoh sehingga pembersihan palka dapat berjalan lancar.

Tabel 2 - Teori Manajemen Pembersihan Muatan Tidak Sejenis

\begin{tabular}{|c|c|}
\hline $\begin{array}{c}\text { APLIKASI } \\
\text { TEORI } \\
\text { MANAJEMEN }\end{array}$ & $\begin{array}{c}\text { PEMBERSIHAN MUATAN TIDAK } \\
\text { SEJENIS }\end{array}$ \\
\hline Planning & $\begin{array}{l}\text { a. Merencanakan kapan } \\
\text { pelaksanaan pembersihan } \\
\text { ini dimulai. } \\
\text { b. Merencanakan } \\
\text { pembersihan dimulai dari } \\
\text { palka yang got hisapnya } \\
\text { lancar. } \\
\text { c. Merencanakan jumlah crew } \\
\text { yang akan melakukan } \\
\text { pembersihan. } \\
\text { d. Merencanakan pembagian } \\
\text { tugas-tugas pembersihan. } \\
\text { e. Merencanakan tahap- } \\
\text { tahap dalam persiapan } \\
\text { pembersihan ruang muatan } \\
\text { curah meliputi cleaning, } \\
\text { washing, drying dan } \\
\text { rechecking. } \\
\text { f. Mengadakan a safety } \\
\text { briefing. }\end{array}$ \\
\hline Organizing & $\begin{array}{l}\text { a. Manusia } \\
\text { Mengorganisasikan siapa } \\
\text { saja crew yang akan } \\
\text { melakukan pembersihan. } \\
\text { b. Alat } \\
\text { Mengorganisasikan } \\
\text { peralatan apa saja yang } \\
\text { digunakan untuk } \\
\text { pembersihan. } \\
\text { c. Waktu } \\
\text { Mengorganisasikan waktu } \\
\text { pembersihan dimulai dan } \\
\text { waktu pembersihanselesai } \\
\text { serta penambahan waktu } \\
\text { pelaksanaan pembersihan } \\
\text { agar cepat selesai. }\end{array}$ \\
\hline Actuating & $\begin{array}{l}\text { Melaksanakan pembersihan } \\
\text { menggunakan fire hose } \\
\text { dengan menyemprotkan ke } \\
\text { dinding-dinding palka. }\end{array}$ \\
\hline
\end{tabular}




\begin{tabular}{|c|c|}
\hline Controlling & $\begin{array}{l}\text { a. Pengawasan mualim } 1 \\
\text { dalam melaksanakan } \\
\text { pembersihan palka. } \\
\text { b. Mualim } 1 \text { harus } \\
\text { menggerakkan para crew } \\
\text { kapal ke arah yang sudah } \\
\text { ditentukan saat melakukan } \\
\text { pembersihan palka. } \\
\text { c. Checklist hasil pelaksanaan } \\
\text { pembersihan. }\end{array}$ \\
\hline
\end{tabular}

Penjelasan untuk pembersihan palka muatan tidak sejenis yaitu:

a) Planning, berbeda dengan perencanaan pembersihan apabila muatan yang akan dimuat selanjutnya sejenis, maka apa apabila muatan yang akan dimuat selanjutnya berbeda jenis perencanaannya juga harus lebih jitu. Perencanaan yang dilakukan antara lain adalah:

(1) Merencanakan kapan pelaksanaan pembersihan akan dimulai, tetapi melakukan pembersihan ini harus sesegera mungkin karena waktu yang diperlukan relatif lebih lama dibandingkan pembersihan muatan yang sejenis, oleh karena itu pembersihan harus segera dilakukan agar palka bersih dan siap dimuat oleh muatan lain. Perencanaan waktu ini juga berpengaruh pada jam istirahat apabila jarak tempuh dekat maka pembersihan bisa dilakukan sampai malam hari, karena waktu normal kerja adalah sampai jam 5 sore.

(2) Merencanakan pembersihan dimulai dari palka yang mana terlebih dahulu. Sebaiknya pembersihan dimulai dari palka yang gotnya bisa menghisap air dengan baik. Karena hal tersebut dapat membuat proses pembersihan semakin cepat selesai.

(3) Merencanakan berapa jumlah ABK yang akan ikut dalam pelaksanaan pembersihan palka. Jumlah ABK yang ikut melaksanakan pembersihan pastinya harus lebih banyak karena waktu untuk menyelesaikan pembersihan ini juga pasti lebih lama dibandingkan pembersihan muatan yang sejenis, selain itu juga pasti melibatkan crew bagian mesin, karena got palka bisa menghisap air dengan pompa hisap yang ada di kamar mesin.

(4) Merencanakan pembagian tugas-tugas yang akan dilakukan oleh ABK, karena akan banyak yang akan dilakukan seperti menyemprot palka dengan air laut, melapor ke kamar mesin untuk menyalakan pompa hisap pada got palka, memasukkan sisa-sisa muatan yang rontok karena semprotan air ke dalam drum dan membuang sisa muatan yang telah dimasukkan ke dalam drum ke laut.

(5) Merencanakan tahap-tahap dalam persiapan pembersihan ruang muatan curah meliputi cleaning, washing, drying dan rechecking. Setelah itu tutup ruang muat (hatchcover) dan peranginan (ventilasi) dibiarkan terbuka untuk mempercepat pengeringan dengan ketentuan keadaan cuuca mengizinkan artinya tidak atau sedang hujan, selain itu untuk mempercepat pengeringan dibagian tanktop yang agak cekung dapat digunakan busa. Lalu setelah tahap cleaning, washing dan drying 
selesai, maka selanjutnya tahap rechecking pengecekan ruang muat seperlunya. Setelah ruang muat kering dan benar-benar bersih, maka biasanya dilakukan penyekrapan dari karat-karat yang ada dalam ruang muat. Kotoran-kotoran karat yang sudah discrap tadi disapu dan dikumpulkan kedalam wadah dan selanjutnya diangkut keatas deck.

Mengadakan safety briefing agar pembersihanberjalan aman.Safetybriefing merupakan suatu pertemuan seluruh crew sebelum melakukan suatu pekerjaan, safetybriefing berisi arahan-arahan dari captain maupun mualim agar pelaksanaan pembersihan palka berjalan aman dan tidak terjadi kecelakaan.

Beberapa hal yang perlu diperhatikan dalam safetybriefing adalah:

a) Memperhatikan keselamatan kerja para crew dengan memperhatikan alat keselamatan kerja (safetyequipment) apakah sudah dikenakan sesuai prosedure.

b) Memperhatikan permintaan para crew untuk fasilitas atau sarana prasarana yang dibutuhkan dalam kegiatan pembersihan palka.

c) Memperhatikan keselamatan kapal dari kerusakan karena benturan dan lain sebagainya akibat dari kelalaian para crew.

d) Organizing, pengorganisasian ini sangat berbeda dengan pembersihan muatan sejenis, langkah-langkah pengorganisasian ini adalah:

(1) Manusia, Pengertian dari manusia tersebut yaitu jumlah ABK atau crew yang akan melaksanakan pembersihan. Karena pembersihan ini akan melakukan proses penyemprotan dengan air laut maka akan butuh jumlah orang yang lebih banyak. Pada proses pembersihan sejenis cukup dengan ABK kapal bagian deck yaitu: bosun, mistri, cadet, dan jurumudi (AB). Namun demikian pembersihan ini lebih lama karena banyak pekerjaan yang harus dilakukan, oleh karena itu bantuan tenaga dari perwira maupun orang mesin dapat membantu mempercepat proses pembersihan palka ini. Walaupun perwira deck sebenarnya tidak harus melakukan pembersihan palka, begitu pun crew mesin yang juga tidak harus melakukan pembersihan, tetapi dengan memperkerjakan crew mesin dan perwira deck maka pekerjaan pembersihan ini menjadi lebih ringan dan dapat selesai tepat waktu dengan tujuan yang harus dicapai yaitu ruang muat yang bersih, kering dan siap untuk dimuati muatan lain.

(2) Alat, Alat-alat yang akan digunakan untuk pembersihan ini antara lain: sapu, sekop, drum yang sudah dipasang seling, scrap, engkrak sertamempersiapkan crane kapal untuk membuang sisa-sisa muatan yang telah dikumpulkan ke dalam drum. Juga dengan menggunakan selang pemadam (fire hose) yang digunakan untuk menyemprot sisa-sisa muatan di palka, busa dan pel untuk menbantu proses pengeringan palka.

(3) Waktu, Pengertian dari waktu tersebut yaitu proses pelaksanaan pembersihan ini membutuhkan waktu lebih lama dibandingkan pembersihan muatan sejenis, karena selain mempersiapkan peralatan yang lebih banyak, terlebih dahulu palka harus 
disapu dari sisa-sisa muatan lalu kemudian disemprot dengan air laut. Oleh karena itu waktu untuk memulai pembersihan bisa lebih awal. Misalnya apabila pembersihan muatan sejenis dimulai pukul jam 08.00 maka untuk pembersihan ini waktu mulai bisa diajukan menjadi pukul 07.00. Begitu pun jam selesainya yang apabila pembersihanmuatan sejenis selesai pukul 17.00 maka pembersihan ini bisa selesai dilakukan pukul 21.00 agar segera cepat selesai.

b) Actuating, pelaksanaan untuk pembersihan ini sesuai yang telah direncanakan yaitu:

(1) Tahap pertama cleaning, Membersihkan ruang muatan dengan penyapuan (sweeping), disekop (shoveling) dan scraping sisa-sisa pemuatan yang ada diruang muat dikumpulkan lalu dimasukkan kedalam satu wadah/drum yang diikat dengan seutas tali lalu ditarik keatas dek dengan menggunakan crane kapal yang selanjutnya akan dibuang kelaut.

(2) Tahap washing dan drying, Pembersihan tahap kedua adalah dengan penyemprotan melalui media air laut dengan tujuan memudahkan proses pembersihan pada ruang muat dari sisa-sisa kotoran. Pompa got harus berfungsi dengan baik agar dapat menghisap air laut sekaligus sisa pupuk yang ada dalam palka, sehingga dapat menghindari genangan air didalam ruang muat. Tahap selanjutnya adalah mengeringkan ruang muat (drying). Drying yaitu pengeringan ruang muat dari genangan air bekas penyemprotan dengan menggunakan pompa hisap pada got palka, setelah pompa tidak memungkinkan lagi untuk menghisap, maka air yang masih tertinggal pada bagian yang berlekuk dikeringkan dengan cara dimopping (pel) bersamaan dengan membersihkan endapan sisa-sisa muatan. Setelah itu tutup ruang muat (hatchcover) dan peranginan (ventilasi) dibiarkan terbuka untuk mendapatkan peranginan dan pengeringan oleh matahari agar mempercepat pengeringan dengan ketentuan keadaan cuaca mengizinkan artinya tidak atau sedang hujan. Selain itu, untuk mempercepat proses pengeringan terutama pada permukaan yang cekung dan dalam got menggunakan busa.

(3) Tahap rechecking, Tahap terakhir adalah pengecekan ruang muat seperlunya.Setelah ruang muat kering dan benar-benar bersih, maka biasanya dilakukan penyekrapan dari karat-karat yang ada dalam ruang muat. Kotoran-kotoran karat yang sudah discrap tadi disapu dan dikumpulkan kedalam wadah dan selanjutnya diangkut keatas deck dengan menggunakan crane kapal yang selanjutnya akan dibuang ke laut.

c) Controlling, merupakan pengawasan oleh mualim 1 dalam pelaksanaan pembersihan ini, tanpa pengawasan oleh mualim 1 proses pembersihan ini bisa menjadi kurang efektif. Pengawasan dapat dilakukan agar pelaksanaan pembersihan ini dapat berjalan sesuai rencana, pengawasan dapat dilakukan dengan mualim 1 ikut serta ke dalam palka dan ikut membantu pembersihan palka sehingga anak buahnya termotivasi untuk bekerja cepat serta semangat melakukan pembersihan. Mualim 1 juga mengawasi bagaimana anak buahnya dalam melakukan pekerjaan pembersihan apakah mereka sudah memakai alat keselamatan seperti safety helmet dan safety shoes karena pada saat menyemprot menggunakan fire hose dengan 
tekanan air yang cukup besar berbahaya. Bisa saja fire hose lepas dari pegangan dan mengenai kepala. Selain itu pengawasan juga dilakukan berdasarkan checklist pembersihan yang sudah ada di kapal MV. VANA sehingga hasil pembersihan palka akan diisikan ke dalam sebuah checklist.

\section{KESIMPULAN}

Berdasarkan uraian dan pembahasan masalah dalam penelitian ini, maka penulis dapat menarik kesimpulan sesuai dengan kondisi yang terjadi di MV. VANA yaitu kondisi saat melakukan proses pembersihan palka, kesimpulan yang dapat diambil adalah sebagai berikut:

1) Gambaran persiapan ruang muatan di kapal MV. VANA terjadi penundaan pemuatan disebabkan karena 3 faktor, yaitu persiapan ruang muat yang kurang baik dan teliti karena kurang pengawasan dari mualim 1, pelaksanaan pembersihan ruang muat yang dilaksanakan oleh crew kapal tergesa-gesa, serta waktu yang relatif singkat dalam pelaksanaan pembersihan palka, karena waktu yang seharusnya diperlukan untuk membersihkan 5 buah palka normalnya adalah 5 hari tetapi waktu pelayaran hanya 3 hari saja.

2) Terjadinya permasalahan dalam pembersihan ruang muatan karena pendekatan teori manajemen belum diterapkan di kapal MV. VANA. Untuk itu pendekatan manajemen yang diterapkan dalam mempersiapkan ruang muatan di kapal MV. VANA adalah merencanakan segalanya terlebih dahulu sebelum melaksanakan proses pembersihan palka seperti merencanakan waktu pelaksanaan, jumlah personil, pembagian tugas-tugas serta dengan melakukan safetybriefing terlebih dahulu agar pelaksanaan pembersihan berjalan lancar. Mengorganisasikan tentang manusia, alat dan waktu pelaksanaan pembersihan sebagai mekanisme membuat perencanaan menjadi kenyataan. Melaksanakan pembersihan sesuai dengan perencanaan dan pengorganisasian yang telah dibuat. Mualim 1 sebagai pemimpin kerja harus melakukan pengawasan pada saat melakukan proses pembersihan lalu membuat checklist tentang pelaksanaan pembersihan palka.

\section{DAFTAR REFERENSI}

Agus Purwanto dan Dyah Ratih Sulistyastuti. 2007. Metode Penelitian Kuantitatif, Untuk Admnisitrasi Publik, dan Masalah-masalah Sosial. Gaya Media, Jogyakarta.

Herujito, Yayat M. 2001. Dasar-dasar Manajemen. Jakarta : PT. Grasindo.

http://juwita.blog.fisip.uns.ac.id. Turner. Pengertian Teori. 06 November 2014.

http://www.bukabuku.com. Rustam, T. Pengertian Teori. 06 November 2014.

http://www.standard-club.com. Crish Spencer. StandardCargo. 08Desember2014.

Manullang. M. 2001. Dasar - Dasar Manajemen. Jakarta : Ghalia Indonesia.

Martopo Arso dan Soegiyanto, 2004, Penanganan Muatan, Politeknik IImu Pelayaran

Semarang, Semarang.

Moleong J Lexy. 2006. Metodologi Penelitian Kualitatif. Remaja Rosdakarya, Jakarta. 
Cahya, Y. A \& Sitepu Firdaus

Sutiyar, Comdr, Thamrin Rais. 2014. Kamus Istilah Pelayaran dan Perkapalan. Politeknik IImu Pelayaran, Semarang.

Team Penyusun PIP Semarang, 2014, Pedoman Penyusunan Penelitian, Politeknik IImu Pelayaran Semarang,Semarang.

Nazir, Moh. (2005). Metode Penelitian. Bogor: Ghalia Indonesia.

Raco (2010). Metode Penelitian Kualitatif. Jakarta: Gramedia Widiasarana Indonesia.

http://mudjiarahardjo.uin-malang.ac.id. Labovitz dan Hagedorn. Pengertian Teori. 06 November 2014 